\title{
Does it pay to be socially responsible for construction companies?
}

Conference or Workshop Item

Accepted Version

Nanda, A. (2018) Does it pay to be socially responsible for construction companies? In: ICISO 2018, 16th - 18th July 2018, Henley Business School, pp. 248-256. doi:

https://doi.org/10.1007/978-3-319-94541-5_25 Available at http://centaur.reading.ac.uk/78041/

It is advisable to refer to the publisher's version if you intend to cite from the work. See Guidance on citing.

Published version at: https://link.springer.com/chapter/10.1007/978-3-319-94541-5_25

To link to this article DOI: http://dx.doi.org/10.1007/978-3-319-94541-5_25

All outputs in CentAUR are protected by Intellectual Property Rights law, including copyright law. Copyright and IPR is retained by the creators or other copyright holders. Terms and conditions for use of this material are defined in the End User Agreement. 


\section{CentAUR}

Central Archive at the University of Reading

Reading's research outputs online 


\title{
Does it pay to be socially responsible for construction companies?
}

\author{
Anupam Nanda ${ }^{10000-0002-3036-5890]}$ \\ ${ }^{1}$ Henley Business School, University of Reading, Whiteknights, Reading, RG6 6UD, UK \\ a.nanda@henley.reading.ac.uk
}

\begin{abstract}
Within the built environment, the Engineering and Construction $(\mathrm{E} \& \mathrm{C})$ companies are very natural resource-intensive in terms of their business operations. In this paper, we focus on publicly listed E\&C companies and analyse the role of Corporate Social Responsibility (CSR) activities on their corporate financial performance. The analytical framework is built around the economic theory of private provision of public goods. A basic Capital Asset Pricing Model (CAPM) is used to empirically examine the testable hypothesis with a panel data comprising 17 major E\&C companies with monthly data over 2000-13. The results indicate that CSR activities can influence financial performance significantly after controlling for the firm size variable. We make use of several measures of CSR activities to test robustness. The broad results are robust to a range of alternative model specifications.
\end{abstract}

Keywords: Built Environment, Corporate Social Responsibility, CAPM.

\section{Introduction}

The role of Corporate Social Responsibility (CSR) in corporate performance has been explored extensively in the literature. While our understanding has improved, it is far from being definitive as findings remain mixed and new issues and challenges have emerged in recent years. With growing concerns around climate change and increasingly loud calls for sustainable business practices from all corners of the society, the role of a corporation is being redefined and broadened to include a stronger commitment to the sustainability issues of respective businesses. Therefore, the companies need to look beyond the Corporate Financial Performance (CFP) and focus on Corporate Social Performance (CSP). A natural question arises: how CSR activities are associated with corporate performances? A substantial share of the economic activities that directly comes under the sustainability scanner is channeled through the built environment. Within built environment, the Engineering and Construction (E\&C) companies are perhaps the most natural resource intensive in terms of their business operations. The E\&C companies, being unavoidably resource-intensive, are often subject to public dissent and face government controls and restrictions. Across the world, the E\&C companies are expected to contribute to the society. Often such activities include mitigation 
of environmental impacts, sustainability goals, investment into social activities, improvement of working conditions, commitment to employee wellbeing etc. The investment community is also very active in terms of prioritizing investible resources in companies with high CSR activities and performance. As a result, the marketplace may recognize the value that CSR activities can bring in terms of enhanced image or brand equity, increased revenue and ease of access to socially responsible funds.

Many studies have contested whether the CSR profile of a company influences its financial performance. This paper focuses on seventeen major E\&C companies in order to identify and evaluate the relationship between their Corporate Social Responsibility (CSR) and their financial performance by using publicly available data and a Capital Asset Pricing Model (CAPM). A number of econometric techniques are employed to extract best possible information from the data in order to inform the research question. To this end, we firstly present the context of our research question with a brief overview of the extant literature. Then, the empirical framework is discussed, followed by data description and results. Finally, some concluding remarks are provided.

\section{Context and Related Literature}

The idea of corporate social responsibility (CSR) came through concerns coming out of sustainable future, global warming and environmental risks. This means, companies will need to invest a part of their hard-earned profit back into society. The argument is: since companies use resources from the society (i.e. people/human capital and natural resources) to fulfil their profit motive, they also need to give back to the society. However, this may also go against the promises to the shareholder of increasing profit/dividend. Milton Friedman famously argued that 'the sole social responsibility of business is to increase its profits'. So, why should a company engage in such activities, which are apparent net draws to their surplus cash?

This question has been repeatedly asked over the last few decades and therefore, the literature is rather extensive. It can be argued that CSR activities should also lead to increased revenue and performance of the company. It can be claimed that CSR activities can improve firms' competitive advantage by attracting socially responsible consumers and as a result of being a 'good corporate citizen', firms can enjoy enhanced image and reputation. Indeed, it is often argued that such brand enhancement and strategic positioning can successfully yield additional advantages linked to insulation from regulatory risk, public dissent, government sanctions and disruptions in activities, due to negative campaigns by social and environmental activists and non-governmental organisations $[1,2]$.

The empirical literature examining the effect of CSR activities on firms' financial performance is long and it is fraught with mixed and inconclusive results $[3,4,5]$. The main reason is our inability to understand the mediating factors and data constraints proving significant in creating estimation biases (for reviews see, $[6,7,8,9]$ and see Fig. 1). In appraising the literature of CSR across the construction industry, Jones et al. [10] investigated the CSR issues of the UK's biggest construction companies. In their paper, they discussed the main characteristics of the CSR and the construction sector 
challenges by using the CSR reports and online published information of the leading construction companies of the UK. Their findings revealed very significant variations in the CSR reporting mainly focusing on environmental issues, but also, their research addressed issues related to health and safety, supply chain management, human resources, the communities, the government, ethics, etc. The authors suggested that although construction companies are taking the CSR principles into consideration, however, their performance indicators show poor evidence towards this direction as well as having low participation rates in the general benchmarking exercises. Moreover, Zhao et al. [11], by taking into consideration the CSR factor and especially its significance in the construction industry, developed a framework for CSR indicators for the construction enterprises globally as a tool for CSR performance. They considered the CSR stakeholders who are involved in the construction sector and proposed a CSR indicator system based on the stakeholders' theory.

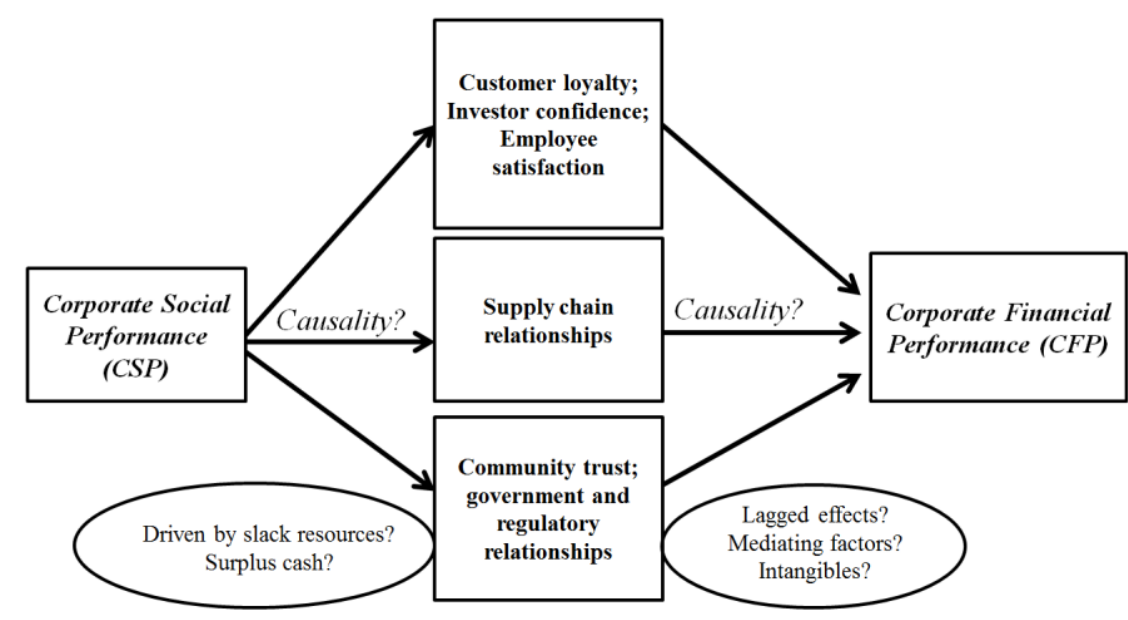

Fig. 1. Conundrum of CSR and Financial Performance

Above literature review indicates that there is a wide-spread recognition of the impact of CSR/sustainability activities on firm-level performances. However, the effect is lot less clear when we try to quantify it. Robust empirical analysis of the dynamic relationship between CSP and CFP requires some consideration of a number of potential issues. Any empirical investigation is fraught with significant data constraints and estimation biases. With these caveats, we move on to an empirical investigation of the relationship between CSP and CFP for seventeen E\&C companies.

\section{Empirical Framework}

In terms of empirical modelling, there are several approaches that have been tried in the literature. Ever since the CSR ratings data became available across a number of 
companies over time, some studies have modelled the effect of the CSR rating on Tobin's $\mathrm{q}$ and total returns. While all modelling approaches are contested on some grounds, there is no definitive agreement in the literature on the best empirical framework. In this paper, we employ a tested and long-established asset pricing model Capital Asset Pricing Model (CAPM). Sharpe's [12] and Lintner's [13] pioneering works, among others, have established the CAPM model as one of the most well-known and most frequently used models. The basic framework is represented as follows:

$$
\left(r_{i t}-r f_{t}\right)=\alpha+\beta_{1}\left(r m_{i t}-r f_{t}\right)+\mathrm{u}_{i t}
$$

$r_{i t}$ is the return rate of firm $i$ 's stock in time $t$; $r f_{i t}$ is the return of a risk-free asset in time $t$ that may correspond to firm $i ; r m_{i t}$ is the market's (benchmark index) return rate in time $t$ that may correspond to firm $i$. The coefficient beta reflects the systematic risk or sensitivity of the expected excess asset returns to the expected excess market returns.

The most stringent criticism against CAPM model has been the low explanatory power or $r$-squared and strong assumptions regarding equal and symmetric information processing by all economic agents. However, the ability to control for other confounding factors into the equation (1) is very useful and can aid in answering many questions. Much like the approach in Cardebat and Sirven [14], we can add other control variables such as CSR and firm size as in equation (2) below.

$$
\left(r_{i t}-r f_{t}\right)=\alpha+\beta_{1}\left(r m_{i t}-r f_{t}\right)+\beta_{2} c s r_{i}+\beta_{3}(\text { other controls })+\mathrm{u}_{i t}
$$

In equation (2), we also add other controls that may potentially impact the firm's performance such as number of employees, market cap and productivity (calculated as market cap per employee). We also try several alternative measures of CSR (see Table 1 for description of variables).

Since our dataset covers 17 firms observed over 157 months (Dec. 2000 - Dec. 2013), we can model equation (2) within panel data framework. The advantage of this method is that it allows us to use both time series and cross sectional variations in the data, which increases the efficiency of the OLS estimates. A typical feature of panel data framework is the presence of unobserved heterogeneity. A potential bias in estimating equation (2) is the presence of correlation between unobserved heterogeneity at the firm level and the observables, which would otherwise violate standard assumptions of OLS estimation. Therefore, the disturbance term in equation (2) is specified as a twoway error component capturing firm-specific fixed effects and time-specific effects.

$$
\mathrm{u}_{i t}=\gamma_{i}+\delta_{t}+\epsilon_{i t}
$$

In this specification, heterogeneity is assumed to be constant over time and correlated with independent variables. The constant effect is removed by mean-differencing the data. This estimation strategy may be consistent with theoretical expectations that firmspecific unobserved characteristics can bring in permanent differences in individual firm's financial and corporate situation.

Finally, due to presence of large variation in firm size, type of business and corporate structure, it is quite likely that the variance of the error term in regression models may be non-constant, which would violate one of the key assumptions of OLS modelling. 
To address this inherent heteroscedasticity problem, we estimate all models with heteroscedasticity-robust standard error.

\section{$4 \quad$ Data, Results and Analysis}

Our data comprises monthly returns across seventeen E\&C companies over 157 months of December 2000 -December 2013 i.e. 2669 panel observations. The time period covered in this study is interesting as we can observe two economic cycles and moreover, the CSR activities and awareness took considerable prominence during this time period. The seventeen companies are:

Fluor Corporation, KBR Inc., URS Corporation, McDermott International, Tutor Perini Corporation, CB\&I/Shaw Group, Jacobs Engineering Group, Granite Construction Inc., Willbros Group Inc., Babcock \& Wilcox Company, Orion Marine Group Inc., Layne Christensen Company, Foster Wheeler AG, First Solar Inc., Matrix Service Company, Great Lakes Dredge \& Dock Corporation and Sterling Construction Company.

Some companies have missing observations over certain period i.e. the regression dataset is an unbalanced panel. The stock price variable is obtained from Google finance (listed in NYSE and NASDAQ) and we use year-over-year return in excess of risk-free rate (10-year US Treasury bond) as the dependent variable. The market benchmark is the Dow Jones Sustainability Index (DJSI). DJSI is very appropriate as a benchmark for our question since it is most well-established and keenly followed market index measuring sustainability performance. The Dow Jones Sustainability World Index was launched in 1999 as the first global sustainability benchmark. The index family tracks the stock performance of the world's leading companies in terms of economic, environmental and social criteria.

The most important variable in question is the CSR measure. We use the CSRHub rating (CSR rating) as a starting point. We have also used the firm's rating compared to all company average of CSR rating (CSR excess). Since there have been significant criticism of such ratings, we have created our own subjective measure of website content on CSR activities to rate companies (CSR web) as follows (as in 2014).

$\mathbf{5}=$ fully dedicated and prominent link in home page with full details across ESG parameters with visible sustainability reports;

4 = dedicated and prominent link in home page with some details across ESG parameters with visible sustainability reports;

$\mathbf{3}$ = webpage with few details across ESG parameters with few visible sustainability reports;

$\mathbf{2}$ = webpage with little details across ESG parameters with no visible sustainability reports;

$\mathbf{1}=$ no webpage with poor details across ESG parameters with no visible sustainability reports; 
Other controls that we have examined are: number of employees obtained from Google Finance and company websites; market cap sourced from Google Finance; productivity calculated as market cap divided by number of employees.

Table 1. Variable Description and Sources of Data

\begin{tabular}{|c|c|c|}
\hline Variable & Description & Sources \\
\hline Stock return & Year-over-Year return & Google Finance \\
\hline Market return & Year-over-Year benchmark return & $\begin{array}{l}\text { Dow Jones Sustainability } \\
\text { Index - http://www.sus- } \\
\text { tainability-indices.com/ }\end{array}$ \\
\hline Risk free rate & 10 Year Treasury Yield & US Federal Reserve \\
\hline Employees & $\log ($ no. of employees $)$ & $\begin{array}{l}\text { Company Websites, } \\
\text { Google Finance }\end{array}$ \\
\hline Market cap & $\log ($ market cap $)$ & Google Finance \\
\hline Productivity & $\begin{array}{l}\log (\text { market cap divided by no. of } \\
\text { employees) - proxy for produc- } \\
\text { tivity }\end{array}$ & \\
\hline CSR rating & Rating of individual companies & $\begin{array}{l}\text { CSRHub - } \\
\text { https://www.csrhub.com/ }\end{array}$ \\
\hline CSR excess & $\begin{array}{l}\text { CSR Rating compared to the all } \\
\text { company average }\end{array}$ & $\begin{array}{l}\text { CSRHub - } \\
\text { https://www.csrhub.com/ }\end{array}$ \\
\hline CSR web & $\begin{array}{l}\text { Author' subjective evaluation } \\
\text { (scale of } 1-5,5 \text { being best) based } \\
\text { on content on individual company } \\
\text { website }\end{array}$ & Company Websites \\
\hline CSR int & $\begin{array}{l}\text { CSR Rating interacted with } \\
\text { month-to-month return of DJSI } \\
\text { Sustainability Index with all ethi- } \\
\text { cal exclusions }\end{array}$ & \\
\hline
\end{tabular}

We first estimate equations 1 and 2 with the full sample. Table 2 reports seven model specifications. Model 1 is the baseline CAPM model that incorporates the size variables that may explain firm's performance. The number of employees has significant negative effects on excess return and market cap has significantly positive effects. When we add CSR variables in model 2, these results remain qualitatively unchanged. The CSR rating variable is significantly positive, while the $C S R$ web variable affects financial performance negatively. The growing importance of online materials and use of such material for marketing purposes are important and this may play a role in negative effect on firm's performance. To address the problem of estimation in various firm sizes, we have used productivity variable in model 3, replacing other two size variables. It is possible that CSR activities are mostly viewed in a comparative sense i.e. compared with the market or industry standards. Therefore, in model 3, we include CSR excess computed as (all company average minus the firm's CSR rating) and it turned out to be negative which implies that if a company is under-performing compared to the all company average, it can entail significantly negative effect on financial performance. It is 
also important to note that issues of multicollinearity can be problematic and therefore, we have maintained parsimony in model specification. We find that the multicollinearity issue is not severe in our framework.

Table 2: Full Sample Regression Results

\begin{tabular}{|c|c|c|c|c|c|}
\hline & (1) & (2) & (3) & (4) & (5) \\
\hline Excess market & $1.421 * * *$ & $1.411 * * *$ & $1.416^{* * *}$ & $1.420 * * *$ & $1.422 * * *$ \\
\hline Return & (25.02) & $(24.91)$ & $(25.11)$ & (21.30) & $(21.36)$ \\
\hline \multirow[t]{2}{*}{ CSR rating } & & $0.009 * * *$ & & & \\
\hline & & $(3.30)$ & & & \\
\hline \multirow[t]{2}{*}{ CSR web } & & $-0.042 * *$ & & & \\
\hline & & $(-3.04)$ & & & \\
\hline \multirow[t]{2}{*}{ CSR excess } & & & $-0.006^{*}$ & & \\
\hline & & & $(-2.08)$ & & \\
\hline \multirow[t]{2}{*}{ CSR int } & & & & 0.006 & $0.037 * *$ \\
\hline & & & & $(0.92)$ & (3.04) \\
\hline \multirow[t]{2}{*}{ Employees } & $-0.038 * *$ & $-0.027^{*}$ & & & \\
\hline & $(-2.94)$ & $(-2.08)$ & & & \\
\hline \multirow[t]{2}{*}{ Market cap } & $0.056^{* * *}$ & $0.069 * * *$ & & & \\
\hline & $(4.33)$ & $(5.55)$ & & & \\
\hline \multirow[t]{2}{*}{ Productivity } & & & $0.055^{* * *}$ & $0.076^{* * *}$ & $0.083^{* * *}$ \\
\hline & & & $(4.36)$ & (7.74) & $(8.07)$ \\
\hline \multirow[t]{2}{*}{ Intercept } & $-0.408 * *$ & $-1.051 * * *$ & $-0.238 * *$ & $-0.387 * * *$ & $-0.402 * * *$ \\
\hline & $(-3.17)$ & $(-5.04)$ & $(-2.89)$ & $(-4.74)$ & $(-5.56)$ \\
\hline $\begin{array}{l}\text { Model Specifica- } \\
\text { tion }\end{array}$ & OLS & OLS & OLS & $\begin{array}{l}\text { Random } \\
\text { Effects }\end{array}$ & $\begin{array}{l}\text { Company } \\
\text { Fixed Ef- } \\
\text { fects }\end{array}$ \\
\hline R-squared & 0.198 & 0.204 & 0.198 & 0.189 & 0.241 \\
\hline $\mathrm{N}$ & 1969 & 1969 & 1969 & 1969 & 1969 \\
\hline
\end{tabular}

$\mathrm{t}$ statistics based on robust standard error in parentheses;

$\sim \mathrm{p}<0.1 ; * \mathrm{p}<0.05 ; * * \mathrm{p}<0.01 ; * * * \mathrm{p}<0.001$

Models 1 through 3 in Table 2 do not control for unobserved heterogeneity. As explained before, it is possible to model unobserved heterogeneity in two ways - random effects and fixed effects. In model 4, we assume random effects and we assume fixed effect structure in model 5. We have performed Hausman specification test considering both models 4 and 5, and the results consistently suggested that a fixed effects specification was more appropriate [15]. Therefore, we take model 5 forward. The explanatory power $(24 \%)$ of model 5 is highest among all models in Table 2 while this level of $\mathrm{r}$ squared is not ideal but compared to many studies this is reasonable. In models 4 and 5, our CSR measure is time-varying, CSR int. Specifically, we interact CSR excess with 
DJSI total return with all ethical exclusion tags such as alcohol, tobacco, gambling, armaments, cluster bombs, landmines, firearms, nuclear and adult entertainment. While a valid concern against such interaction term is multicollinearity, we have found very low correlation (negative 3.1\%) between CSR int and Market return. Moreover, such measure is valid as it compares CSR activities with that of all company average and also with the stringent DJSI sustainability index. We find significant positive effect (0.037) of excess CSR activity on financial performance in model 5. In our modelling framework and hypothesis testing, sign and significance of the effect is more relevant than the size of the coefficient. In general, we find that the CSR measures have significant effect on financial performance according to the CAPM modelling framework.

\section{Conclusion}

Being resource-intensive, the E\&C companies often face government sanctions, public dissent and disruption of operations. The outcry of complying with strict sustainability regulations is perhaps louder for $\mathrm{E} \& \mathrm{C}$ companies than many other sectors. Therefore, it is quite an interesting exercise to study whether a 'responsible' E\&C company 'does well by doing good' to the society. The empirical investigation of this question is fraught with many challenges starting with lack of good quality data on CSR activities.

In this paper, we focus on seventeen publicly listed E\&C companies and analyse the role of their CSR activities on their corporate financial performance. The analytical framework is built around the economic theory of 'private provision of public goods'. We use basic Capital Asset Pricing Model (CAPM) to empirically examine the testable hypotheses. The model is enhanced by adding firm size and productivity controls that can boost the explanatory power of the specifications. Fixed effect modelling approach has been adopted to mitigate any attenuation bias in estimates from unobserved heterogeneity. The analysis of monthly data over Dec. 2000 - Dec. 2013 reveals that CSR activities can significantly influence financial performance after controlling for firm size variable. The broad results are robust to several alternative model specifications. More data and better estimates of CSR activities are some areas of future research.

\section{References}

1. Bagnoli, M., Watts, S.: Selling to socially responsible consumers: competition and the private provision of public goods. Journal of Economics and Management Strategy 12(3): 419445 (2003).

2. Maxwell, J., Lyon, T., Hackett, S.: Self-regulation and social welfare: The political economy of corporate environmentalism. Journal of Law and Economics 43(2): 583-618 (2000).

3. McWilliams, A., Siegel, D.: Corporate social responsibility and financial performance: correlation or misspecification? Strategic Management Journal 21(5): 603-609 (2000).

4. McWilliams, A., Siegel, D.: Corporate social responsibility: a theory of the firm perspective. Academy of Management Review 26: 117-127 (2001).

5. McWilliams, A., Siegel, D., Wright, P.: Corporate social responsibility: strategic implications. Journal of Management Studies 43: 1-18 (2006). 
6. Stanwick, P., Stanwick. S.: The Relationship between Corporate Social Performance, and Organizational Size, Financial Performance, and Environmental Performance: An Empirical Examination, Journal of Business Ethics 17(2): 195-204 (1998).

7. Roberts, P., Dowling, G.: Corporate reputation and sustained superior financial performance. Strategic Management Journal 23(12): 1077-1093 (2002).

8. Margolis, J., Elfenbein, H., Walsh, J.: Does It Pay to be Good? A Meta-Analysis and Redirection of Research on the Relationship Between Corporate Social and Financial Performance. Mimeo, Harvard Business School, Boston, MA (2007).

9. van Beurden, P., Goessling, T.: The Worth of Values - A Literature Review on the Relation Between Corporate Social and Financial Performance. Journal of Business Ethics 82(2): 407-424 (2008).

10. Jones, P., Comfort, D., Hiller, D.: Corporate Social Responsibility and the UK Construction Industry. Journal of Corporate Real Estate, 8:3, 134-150 (2006).

11. Zhao, Z., Zhao, X., Davidson, K., Zuo, J.: A corporate social responsibility indicator system for construction enterprises, Journal of Cleaner Production. 29-30, 277-289 (2012).

12. Sharpe, W.: Capital Asset Prices: A theory of Market Equilibrium under Conditions of Risk. Journal of Finance 19: 425-442 (1964).

13. Lintner, J.: The Valuation of Risk Assets and the Selection of Risky Investments in Stock Portfolios and Capital Budgets, Review of Economics and Statistics 47: 13-37 (1965).

14. Cardebat, J., Sirven, N.: What corporate social responsibility reporting adds to financial return? Journal of Economics and International Finance 2(2), 020-027 (2010).

15. Hausman, J.: Specification Tests in Econometrics, Econometrica, 46(6):1251-1271 (1978). 